\title{
The Iterability of the Woman Condition: a Derridean Reading of Glaspell's Trifles
}

\author{
Noorbakhsh Hooti ${ }^{1} \&$ Mohammad-Javad Haj'jari² \\ ${ }^{1}$ Associate Professor in Dramatic Literature, Razi University, Iran. E-mail: nhooti@yahoo.com \\ ${ }^{2}$ PhD Student, Razi University, Iran.E-mail:aminhajjari@gmail.com
}

Received April 22, 2016; Revised July 12, 2016; Accepted July 25, 2016; Published August 18, 2016

\begin{abstract}
Derrida defines artifactualities as artificially made norms by institutions and hierarchies which turn into conventions over time in dominating mankind, conventions which must be recognized and dismantled. Every particular event or presence can assume its singularity outside such biased tautology by iterating itself to generate its own specific body of norms in supplementing itself. Accordingly, this study tries to highlight the female logic and the iterability of the woman condition against patriarchal artifactualities in Glaspell's Trifles (1916). The women of the play illuminate a world invisible to patriarchy, an overlooking gaze blurred by artifactualities. Dismantling the binary opposition of male/female, the play highlights the singularity of females in discussing the truth of its events. Moreover, the women's aporetic decision in the play not to reveal Minnie's killing motive is an attempt to defend the female cause and highlight the iterability of the woman condition against patriarchy. Thus, the researchers aim at interpreting Trifles through a Derridean perspective to dig up and open up the stifled woman question against patriarchal artifactualities. Contrasting the collective female knowledge to logocentrism, this study illuminates Glaspell's attempt at foregrounding the unique sphere of women's knowledge over patriarchal artifactualities. Glaspell anticipates Derrida's remarks in turning logocentrism and artifactualities over their heads in favor of the singularity of any phenomena which can iterates itself to proof its unique position outside artifactialities.
\end{abstract}

Keywords: artifactualities, deconstruction, iterability, Trifles, woman condition

\section{Introduction}

Trifles (1916) is based on a true event in Iowa at the turn of the century while Glaspell was a reporter for Des Moines News and thus covered the murder trial of Margaret Hossack, a farmer's wife, accused of killing her sleeping husband, John, with an axe. In covering the case, Glaspell came to sympathize with Margaret when she recognized Margaret's abuse by her husband. This event inspired Glaspell's contribution to the event (Galens, 2000).

Trifles is "a murder mystery" exploring "gender relationships, power between the sexes, and the nature of truth" (Galens, 217). A farmer, John Wright, has been strangled in his bed while sleeping. His wife, Minnie, is the first suspect and in custody. The county attorney, George Henderson, and the sheriff, Henry Peters, are exploring the victim's house with John's neighbor, Lewis Hale. While they are searching for clues upstairs and around the farmhouse, Mrs. Hale and Mrs. Peters discover bits of evidence as motivations for John's murder in Minnie's "trifles"- her

(c) AesthetixMS 2016. This Open Access article is published under a Creative Commons Attribution Non-Commercial 4.0 International License (http://creativecommons.org/licenses/by-nc/4.o/), which permits non-commercial re-use, distribution, and reproduction in any medium, provided the original work is properly cited. For citation use the DOI. For commercial re-use, please contact editor@rupkatha.com. 
baking, cleaning, and sewing stuff. Because the men virtually ignore such womanish stuff, they remain blind to the truth of the murder lying before them.

Many articles have covered Glaspell's feministic defense of the woman cause within Trifles, with Mrs. Hale and Mrs. Peters as spokespersons who, awakened by Minnie's evolutionary action, represent united women subjugated under patriarchy in general. Accordingly, Smith (1982) defines the two women's decision at the end of the play as "female bonding" (192); Alkalay-Gut (1984) names their bondage "the community of women" (1); Ozieblo (2008) emphasizes "the importance of women bonding" (66); Kim (2010), in his study over Glaspell's short story version of the play, "A Jury of Her Peers" (1917), holds that the women's decision to keep Minnie's secret can be taken "as a female mode of ethics"; and Shih (2013), emphasizes "the importance of sisterhood" (243). Glaspell in fact highlights the two women's different perceptions and "the process of persuasion and alliance between them." The play illuminates the role of political power in protecting the law and in unfolding "the women's alliance, decision, and action." Kim mentions Derrida to observe that "the authority of the law itself comes from political power and its interpretative and performative force." Glaspell thus presents the women's decision and action "as a resistance to the existing power of law". This shows that "disparity in modes of perception and action" lead to different judgments, and that movements toward justice may sometimes entail a decision which cannot be supported by present laws (26). In a world "where men define the law and the language" of all, women cannot possess a separate identity (Fernandez-Morales, 2002: 166). Thus, in Derrida's view, an act which can no longer answer "the demands of theoretical rationality" can be "a movement toward justice, making possible the transformation and the refounding of law and politics" (Kim, 26).

Since the dominant attitudes of our societies have valued "customary male activities" over "customary female activities" (Motz, 1988: 2), women have always been suppressed under the binary gendered-biased opposition of man/woman. Such subjugation has not been altogether explicit. Women's internalization of the patriarchal logos proves itself when women see men's superiority over them as virtues and their own shortages as natural facts. It is to accept the binary opposition of rationality/sensation, sensation being always attributed to women. A Derridean reading of Trifles thus seems satisfactory to defend the woman cause. Glaspell has in fact deconstructed "the very assumptions about the incontrovertibility" of all "absolutist" laws (BenZvi, 2005: 175). When it comes to deconstruction, binary pairs are dismantled, the secondary terms acquiring an equal status with the primary ones. Women can therefore hold an equal position of authenticity before patriarchal covert subjugations.

\section{Discussion}

In what follows, Glaspell's defense of the woman cause has been elaborated through three main Derridian concepts: artifactualities, iterability, and aporia. Under each concept, it has been tried to highlight Glaspell's attempts at deconstructing patriarchy for the woman cause.

\subsection{Covert Social Artifactualities}

"Actuality" is a construct and always molded through "institutions, hierarchies, economies, technologies and an array of interests and forces" which individuals are better to recognize, since these forces often "conspire to naturalize or impose a precritical sense of the actual" over mankind (Wortham, 2010: 20). Derrida (1986) coined the term "artifactuality" to say that actuality is 
not given but actively produced, sifted, invested, performatively interpreted by numerous apparatuses which are factitious or artificial, hierarchizing and selective, always in the service of forces and interests to which "subjects" and agents (producers and consumers of actuality - sometimes they are "philosophers" and always interpreters, too) are never sensitive enough. (3)

Derrida thus defines artifactuality as something "produced" by political and social centers than reality (Lucy, 2004: 2). Over time such artifactualities become so naturalized that their lack of genuineness is concealed. For example, patriarchy is a system of subjugation which neutralizes women so that they cannot act independently. Such naturalization of oppression is an artifactuality, or a construct, in disguise. Hence its covertness. In her reading of the short story version of Glaspell's play, Fetterley (1982) remarks that Glaspell's story "is nothing less than the story of men's systematic, institutionalized, and culturally approved violence towards women" (153).

Trifles opens with the entrance of two groups of men and women, respectively: the Attorney, the Sheriff, and a farmer as the male group and the Sheriff and the farmer's wives as the female one. Initially, while these men are presented with their names, the women are called by their husbands' surnames. It is merely Mrs. Hale who refers to the suspect woman as Minnie Foster, her maiden name, than Mrs. Wright by which the men always address Minnie. Addressing married women by their husbands' surnames stresses "the female loss of legal identity after marriage" (López Rodríguez, 2002: 9). Moreover, Minnie's married name "is an ironical pun on her rights under the law" (Ozieblo, 67).

The case is a murder for investigation. Henderson, the Attorney, suggests that they look around the house for clues, beginning with the room of the murder and then the barnyard, ignoring the kitchen where Minnie was sitting after the murder. But it is those very kitchen things which prove the most telling clues about the murder. As we have it in the scene:

Attorney. ... I guess we'll go upstairs first - and then out to the barn and around there. (To the SHERIFF.) You're convinced that there was nothing important here - nothing that would point to any motive?

Sheriff. Nothing here but kitchen things.

Mrs. Peters. (to the other woman) Oh, her fruit; it did freeze. (To the Lawyer.) She worried about that when it turned so cold...

Sheriff. (rises) Well, can you beat the woman! Held for murder and worryin' about her preserves.

Attorney. ... I guess before we're through, she may have something more serious than preserves to worry about...

Hale. Well, women are used to worrying over trifles...

Attorney. [...] And yet, for all their worries, what would we do without the ladies? (Glaspell, 2006: 1035-36)

Women here are initially portrayed as fixed identities who just care about trivial details which men simply ignore, while as the female sex they are required for housekeeping, against which Mrs. Hale reacts:

Mrs. Hale. (looking about [the house]) It never seemed a very cheerful place. 
Attorney. No - It's not cheerful. I shouldn't say she had the homemaking instinct.

Mrs. Hale. Well, I don't know as Wright had, either.

Attorney. You mean that they didn't get on very well?

Mrs. Hale. No, I don't mean anything. But I don't think a place'd be any cheerfuller for John Wright's being in it. (1036)

The Attorney, ironically as his profession has been chosen by Glaspell, does not even consider his statement about Minnie's housekeeping as negative. That is the cause for the intentionality which happens in the conversation between Mrs. Hale and the Attorney. Later, the overlooking outlook towards women is repeated again. While the women are examining Minnie's stuff both out of their curiosity and common womanly experiences, the men's fixed image of them as doing trivial things is repeated again:

Mrs. Peters. She was piecing a quilt.

Mrs. Hale. It's a log cabin pattern. [...] I wonder if she was goin' to quilt it or just knot it? [...]

Sheriff. They wonder if she was going to quilt it or just knot it! (The men laugh, the women look abashed.) (1039)

Women's degradation by patriarchy, in Derridean terms, is a covert impure hospitality towards them. Among the men, the Attorney and the Sheriff mostly mock the women. And as the representatives of the judicial system, they play the spokespersons of patriarchy in degrading women. Since the degradation of women and their feelings have been fixed within patriarchy, direct and conditional oppositions to women are not necessary. Through men of law's verbal mockery, women should remind themselves that their feelings and thoughts are trivial:

Mrs. Hale. (resentfully) I don't know as there's anything so strange, our takin' up our time with little things while we're waiting for them to get the evidence...

Mrs. Peters. (apologetically) Of course they've got awful important things on their minds. (1039)

And between the two women, Mrs. Peters is the one mostly under logocentric dominancy. She is a sheriffs wife and double-bounded to the system as both a woman and a man of law's wife:

Mrs. Peters. Mr. Henderson said coming out that what was needed for the case was a motive; something to show anger, or - sudden feeling. (1038)

while Mrs. Hale, a farmer's wife, has purer womanly senses which are sympathetic with her gender:

Mrs. Hale. ... I don't see any signs of anger around here. ... Wonder how they are finding things upstairs... You know, it seems kind of sneaking. Locking her up in town and then coming out here and trying to get her own house to turn against her! (1038)

Mrs. Peters. But, Mrs. Hale, the law is the law. (1039)

It is only Mrs. Peters' status as a woman "married to the law" which can only give her some trustful image:

Sheriff. Do you want to see what Mrs. Peters is going to take in? [...] 
Attorney. Oh, I guess they're not very dangerous things the ladies have picked out... No, Mrs. Peters doesn't need supervising. For that matter a sheriff s wife is married to the law. Ever think of it that way, Mrs. Peters?

Mrs. Peters. Not-just that way...

Sheriff. (chuckling) Married to the law... (1043-44)

And even such role for a woman cannot be that much serious in patriarchy, as the Sheriff is "chuckling", because a woman is a woman, no matter married to the law or not.

In general, the difference between men and women in Trifles is a "difference between male and female spheres," represented by locations each group occupies in it (López Rodríguez, 12). The two women remain, as Glaspell specifies, by the kitchen door as silent and anguished onlookers from a different sphere of life, implying "the lack of interaction" between men and women (Ozieblo 59). The men "stomp about loudly and authoritatively" without finding any clues, being unable to see into such "quiet, domestic" trifles as "the disordered kitchen, ragged sewing, and strangled canary", while these are taken passionately by Mrs. Peters and Mrs. Hale based on which they realize that "the isolated Minnie" could no longer stand further abuse from her “cold, stingy husband” (Makowsky, 61-62). This issue criticizes men's freedom before women's restriction, a restriction paradoxically enabling Mrs. Hale and Mrs. Peters "to decode the information provided by the domestic objects" of Minnie's world. They do not seemingly suffer from "an abusive husband" but from "an abusive society" subjugating them because of their gender. As a further instance, the Attorney's conviction that "it's all perfectly clear except a reason for doing" the murder (Glaspell, 1044), being deconstructed, implies that Minnie's motive is indeed clear but "an all-male jury" can never discover it (Ozieblo, 64). This issue highlights the presence of "two different modes of judging" (Mael, 1989: 283), or "two models of perception of behavior" (Holstein, 2003: 282), between males and females who may then judge differently in different situations.

\subsection{The Iterability of the Woman Condition}

Derrida (1988) suggests that "iterability" is "the logic that ties repetition to alterity" (7). Accordingly, each "irreplaceable event" is "unique", simultaneously manifesting or inscribing itself "on the condition of a possible re-marking." Thus, the "singular" is always iterable (Wortham, 78). Iterability has as its company "a capacity to be repeated in principle" continuously in different contexts while being simultaneously "singular every time" (Royle, 2003: 68). Iterability is not "an extrinsic and dispensable 'extra" coming after "an original form or presence"; iterability implies "a supplementarity that goes all the way down" (Wortham, 78). Thus, iterability involves "both 'repetition' (sameness) and 'alterity' (difference)" (Royle, 68). It refers to the "structure of repetition-as-difference" (Lucy, 59).

As for Trifles, the play can support "the idea of a pre-existing female nature in need of empowerment" within the patriarchy itself (Hinz-Bode, 2006: 65). Sympathizing with Minnie, Mrs. Hale and Mrs. Peters consider themselves and Minnie as "instance[s] of the same, the general, the others," to which they resemble and belong (Lucy, 59). A woman in herself belongs to the general form of women whom she is representing. The only difference between them is alterability and that is because, as Makowsky (1993) holds, Mrs. Hale and Mrs. Peters's sympathies with Minnie derive from both their "sisterly solidarity" and "self-identification as mothers", contrasting "the childless Minnie" (62). Their construction of Minnie's identity, moreover, depends on their recognition of two issues: "the ability of experiential knowledge to determine truth and the possibility of extrapolating from their own experiences to those of another woman" 
(Chung, 1999: 4). They transfer their own subjective experiences to Minnie. Several instances happen when they are to share such experiences with each other, as Mr. Hale announces that "women are used to worrying over trifles" (Glaspell, 1036). The point is that the "men's patronizing attitude" makes the women of the paly ignore "their class differences" and come "closer together, both physically and emotionally"; the women thus make "a bond of sisterhood with the absent Minnie” (López Rodríguez, 12). Later, for Mrs. Hale, "men's intrusion into Minnie's kitchen" becomes an intrusion into hers (Chung, 4). She states that "I'd hate to have men coming into my kitchen, snooping around and criticizing" (Glaspell, 1037). Because Mrs. Hale is disturbed by "men's trivialization" of Minnie's daily work, which resembles her own work as a farmer's wife, she envisions Minnie similarly disturbed were she there to witness the decayed cherries (Chung, 4). According to Mrs. Hale, Minnie felt "awful bad after all her hard work in the hot weather. I remember the afternoon I put up my cherries last summer” (Glaspell, 1037).

Glaspell also shows "how language, in its expression of experience, can elide differences and construct subjectivities” (Chung, 5). Speaking to Mrs. Peters about Minnie's absence from the Ladies Aid, Mrs. Hale says that, "I suppose she felt she couldn't do her part, and then you don't enjoy things when you feel shabby" (Glaspell, 1038). The "web of pronouns" in Mrs. Hale's statement in fact unites her and the other two women within "a community with shared experiences and personal narratives" (Chung, 5). She further sympathizes with Minnie's loneliness, childlessness, and innocence: "Not having_children makes less work... but it makes a quiet house" for Minnie; that having to pass the time with Mr. Wright is "Like a raw wind that gets to the bone (Glaspell, 1040-41). Also, referring to a similar event like what has happened to Minnie's bird, Mrs. Peters highlights Minnie's revenge as if it was hers: "When I was a girl - my kitten - there was a boy took a hatchet, and before my eyes - and before I could get there-(Covers her face an instant). If they hadn't held me back I would have ... hurt him" (1042). Later, addressing Mrs. Peters, Mrs. Hale explains the female experience represented through her sympathies with Minnie's loneliness as such: "I might have known she needed help! I know how things can be for women. I tell you, it's queer, Mrs. Peters. We live close together and we live far apart. We all go through the same things. It's all just a different kind of the same thing" (1043). Mrs. Hale thus wishes for in "a new, communal, female subject" and a "new sense of community" (Chung, 5). Glaspell's incorporation of the two women's "personal testimony" and the exposition of their "immediate experience", as they recognize the men's mockery, highlight Minnie's condition as a "continuum of men's cruelty towards women and their neglect of women's experiences". In essence, the "men's systematic construction of a social narrative" concerning women in general and Minnie in particular becomes a commentary upon women (Chung, 4). That is why the play is usually used as an example of "the bonding between women" against "injustice and domestic violence" (Ozieblo, 14). Women's "sisterhood" thus indicates their "dissatisfaction" with patriarchy and "their determination to shake the social system" (Shih, 247). Accordingly, the iterability of the woman condition implies that "for a thing to be what 'it' is, it must be able to be repeated" (Lucy, 59), and that is what the two women of the play do.

\section{3 Aporia: Hiding the Killing Motive}

"Aporia" is "an undecidable question" (Derrida, 1993: 7); "the difficult or the impracticable, here the impossible, passage, the refused, denied, or prohibited passage, indeed the nonpassage, which can in fact be something else, the event of a coming or of a future advent" (8). It is "where we are exposed, absolutely without [...] possible substitution, singularly exposed in our absolute and absolutely naked uniqueness, [...] disarmed, delivered to the other, incapable even of sheltering ourselves behind what could still protect the interior of a secret" (12). Aporia implies "doubt" or 
"difficulty in choosing", and aporias are concerned with "matters of life and death, law, ethics, politics and justice" (Royle, 92). Thus, the problem is to choose, in a climactic situation in life, a path untrodden before. It is to be "before a door, a threshold, a border, a line, or simply the edge or the approach of the other as such" (Derrida, 1993: 12). It is to be concerned with "put[ting] in motion a new thinking of the possible" (2002:361).

Mrs. Hale and Mrs. Peters' decision not to reveal the killed canary as Minnie's killing motive is an attempt to defend the female cause against patriarchy. Accordingly, revealing the bird would have been a final blow at Minnie through the hands of her own peers who are also under patriarchy. As Wortham says,

Aporias confront us with entirely undecided and indeed undecidable 'situations' that deeply interrupt and suspend all established programs, norms, conventions, moralities, duties and expectations, precisely so as to open anew the possibility of decision, response and responsibility, perhaps even experience itself. To endure the 'impossibility' of an aporia is thus to risk the chance of an 'other' possibility, an impossible possibility that is perhaps the only one worth its name. (15)

Likewise, defending the female cause, Mrs. Hale and Mrs. Peters do not reveal the bird and open up new possibilities of change in the woman condition. The Attorney's statement concerning women's cases is revealing by what happen afterwards:

Attorney. [...] it's all perfectly clear except a reason for doing it [the murder]. But you know juries when it comes to women. If there was some definite thing... Something to show something to make a story about - a thing that would connect up with this strange way of doing It--

To which Mrs. Hale quickly responds as she agitatedly "snatches the box and puts it in the pocket of her big coat" (Glaspell, 1043). The Attorney, who has just entered, addressing the Sherriff, discusses Minnie's quilt:

Attorney. [...]... at least we found out that she was not going to quilt it. She was going to what is it you call it; ladies?

Mrs. Hale. [...] We call it - knot it, Mr. Henderson. (1044)

The Attorney may not fully understand Mrs. Peters' witty answer, which is to defend Minnie. As López Rodríguez says,

Being a textile sandwich of three layers, quilts demanded some way of keeping all the elements together; this could be done in two ways: either by quilting it or by knotting it. Quilting demanded a big frame in which to set the bedcover and many hours of fine stitching which was usually done by a group of women known as a quitting bee. Knotting, however, was easier, faster, and could be done by a single person. (16)

Fiercely isolated by an anti-social husband, Minnie has no female company in helping her with her quilting; she thus has to knot it on her own. If she had the company of friends to withstand her loneliness, "she would have succeeded in keeping a home and would not have knotted a rope around her husband's neck" (16).

Minnie's quilt is a main symbol of the play. Selecting quilting as Minnie's entertainment at home and the connotation of "knot", in the sense of entangling, highlight Minnie's killing manner. Defending the woman cause, Mrs. Hale holds that "We call it - knot it", expressing the action through first person plural, which can be an instance of the iterability of women's 
experiences. Mrs. Peters and Mrs. Hale, to help Minnie, willingly try to defy patriarchy and "not only solve the mystery but also develop their sense of identity as women with Minnie" and prove their bondage with her by trying "to protect her from male law and judgment" (Hedge, 1995: 49). Their experiences with the Attorney and their husbands show that women's "sense of legal and moral judgment" differs from those of men, a fact which makes them covertly defend Minnie against "the judgment of an unjust system" (Chung 3-4). "The last laugh" belongs to the women (Hedge, 61), who manifest "female solidarity" by hiding the dead bird and their findings from the men (Makowsky, 62). Thus, the two women's decision by not to reveal the bird is aporetic as an instance of evolutionary action against patriarchy. As Shih says, "There exists the possibility of social change by man-made effort and social construction instead of being static and descriptive only" (251). However, Mrs. Hale and Mrs. Peters' "rebellion" is not an "active insurrection" but a "passive resistance" which is all they can do in that situation (63). What is necessary is to make amendments for "female powerlessness and disenfranchisement". Covertly highlighting women's powerlessness under patriarchy, Glaspell presents us with "the potential for female action and usurpation of power", manifested through Mrs. Hale and Mrs. Peters' senses of investigation (BenZvi, 175).

Glaspell had already depicted in Trifles the "inequities of the United States judicial system," a "literally impossible" space "for a woman to have 'a jury of her peers"” (Gainor, 2008: 74). Derrida (1990) declares that deconstruction is "mad about justice" (965). Like deconstruction and democracy, justice entails a sense of "yet, to come" (969). Encountering "the undecidable, aporia, and incalculability," justice is concerned with the "experience of the impossible" (947). "Justice, however unpresentable it may be, doesn't wait. It is that which must not wait" (967). Likewise, Glaspell has created "a new type of modern theatre" which is not based on observable actions by characters but on readable or interpretable actions. Accordingly, "a psychological narrative" is constructed (Mulry, 2014: 293), which is subjected to "subjective frames of reference" (Ben-Zvi, 174). Therefore, the men of the play may not be able to read the women's action appropriately; since women's worldview is different from that of men, they see into things differently, in a way invisible to men. As the anthropologist Edward T. Hall says, "Men and women grow up in cultures that can be considered distinct." As such, they see the world differently. And while "women are likely to perceive details", men pay attention to "whole pictures" (quot. in Forrest \& Blincoe, 1952: 238).

The iterability of the woman condition ignites revolutionary attempts to overthrow the logocentric system. Mrs. Hale, not considering the murder unjust, plays the spokesperson of the female cause. Hiding the grave-box, simultaneously as it defends Minnie, implies that the female cause is not understandable for patriarchy. The knowledge acquired accordingly, Minnie's killing motive, is the tool empowering the two women to subdue patriarchy. And we see these women "transform[ing] from observers to actors" assuming the authority to decide what to do with such knowledge (Ozieblo, 62), implying that a murder can be an act of "justifiable homicide by a battered woman" (Bryan, 1997: 1296). Mrs. Hale and Mrs. Peters are not disinterested in solving Minnie's case; in fact they cooperate for the sake of "a knowledge essential for their survival as females in a hostile or indifferent world" (Stein, 1987: 256).

\section{Conclusion}

Although Glaspell's women play a passive role in the course the play, their underlying curiosity points to their invisible knowledge over which men have no access. As such, the female 
knowledge, represented through Mrs. Pale and Mrs. Peters' covert investigation into Minnie's case, works against the logocentric patriarchy which considers the details of women's lives as mere trifles. Minnie's world, which is invisible to the male gaze, can only be interpreted by women of her own kind, or as the play suggests, women in general who feel the same regarding domestic affairs. As such, Mrs. Pale and Mrs. Peters act against the patriarchal artifactualities, manifested through the male figures of the play and their speech in mocking womanly affairs. Patriarchy's inability to comprehend the state of women, their mentality, and their sphere of knowledge highlights the secondary term in the traditional binary opposition of male/female, a fact which empowers women over men regarding specific issues. The two women's aporetic decision not to reveal their own clues about the murder, clues which are in fact against Minnie, acts towards dismantling this binary pair and defending the woman cause. And in defending it, the women become the same in following the same path towards their rights, although their individual lives are different. Hence, the iterability of the women condition; while living their individual lives, women share the same concerns and feelings in making a unity against patriarchy.

\section{References}

Alkalay-Gut, Karen. (1984). "Jury of Her Peers: The Importance of Trifles." Studies in Short Fiction, 21(1), 1-9.

Ben-Zvi, Linda. (1995). “Introduction.” Susan Glaspell: Essays on Her Theater and Fiction, ed. Linda Ben-Zvi. Ann Arbor: The University of Michigan Press.

---. (2005). Susan Glaspell: Her Life and Times. Oxford: Oxford University Press.

Bryan, P. (1997). "Stories in Fiction and in Fact: Susan Glaspell's 'A Jury of Her Peers' and the 1901 Murder Trial of Margaret Hossack." Stanford Law Review, 49, 1293-1363.

Chung, Kathy K.Y. (1997). "A Different Kind of the Same Thing." Theatre Research in Canada 20(2), 1-11.

Derrida, Jacques. (1993). Aporias, trans. Thomas Dutoit. Stanford: Stanford University Press.

---. (2002). "As If It Were Possible," trans. Benjamin Elwood and Elizabeth Rottenberg. Negotiations: Interventions and Interviews, 1971-2001, ed. Elizabeth Rottenberg. Stanford: Stanford University Press.

---. (1990). "Force of Law," trans. Mary Quaintance, Cardozo Law Review, 11(5/6), 921-1045.

---. (1988). “Signature Event Context," trans. Samuel Weber and Jeffrey Mehlman. Evanston: Northwestern University Press.

---. (1986). The Ear of the Other, trans. Peggy Kamuf. New York: Schocken.

Fernandez-Morales, Marta. (2002). "The Two Spheres in Susan Glaspell's Trifles and The Verge." Staging a Cultural Paradigm, eds. Barbara Ozieblo and Miriam López-Rodríguez. Brussels: P.I.E.

Fetterley, Judith. (1982). "Reading about Reading." Gender and Reading, ed. E. A. Flynn and P. Schweickart. Baltimore: Johns Hopkins University Press.

Forrest, John and Deborah Blincoe. (1952). The Natural History of the Traditional Quilt. Austin: University of Texas Press.

Gainor, J. Ellen. (2008). "Woman's Honor and the Critique of Slander Per Se.” Susan Glaspell: New Directions in Critical Inquiry, ed. and Intro. Martha C. Carpentier. New Castle: Cambridge Scholars Publishing.

Galens, David. (200o). Drama for Students, Vol. 8. New York: Gale Group. 
Glaspell, Suzan. (2006). Trifles. Perrine's Literature, Volume 3: Drama. $9^{\text {th }}$ Edition. London: Thomson Wadsworth.

Hedges, Elaine. (1995). “Small Things Reconsidered.” Susan Glaspell: Essays on Her Theater and Fiction, ed. Linda Ben-Zvi. Ann Arbor: The University of Michigan Press.

Hinz-Bode, Kristina. (2006). Susan Glaspell and the Anxiety of Expression. Jefferson, NC: McFarland \& Co.

Holstein, Suzy Clarkson. (2003). "Silent Justice in a Different Key: Glaspell's Trifles.” Midwest Quarterly, 44(3), 282-90.

Kim, Miehyeon. (2010). "Difference and Law in Susan Glaspell's “A Jury of Her Peers.”” Anglo-American Feminist Literature, 18(1), 5-27.

López Rodríguez, Miriam. (2002). "Reading Minnie’s Quilt: Decoding Domestic Material Culture in Susan Glaspell's Trifles.” Madrid: Universidad de Alcalá.

Lucy, Niall. (2004). A Derrida Dictionary. Oxford: Blackwell Publishing Ltd.

Mael, Phyllis. (1989). “Trifles: The Path to Sisterhood." Literature Film Quarterly, 17(4), 281-84.

Makowsky, Veronica. (1993). Susan Glaspell's Century of American Women. Oxford: Oxford University Press.

Motz, Marilyn Ferriz. (1998). “Introduction.” Making the American Home, ed. Marilyn Ferriz Motz \& Pat Browne. Bowling Green: Bowling Green State University Popular Press.

Mulry, David. (2014). “'In the Presence of a Domestic Drama.” The Explicator, 72(4), 293-296.

Ozieblo, Barbara and Jerry Dickey. (2008). Susan Glaspell and Sophie Treadwell. New York: Routledge.

Royle, Nicholas. (2003). Jacques Derrida. London: Routledge.

Shih, Yi-chin. (2013). "Place and Gender in Susan Glaspell's Trifles and Woman's Honor." Humanitas Taiwanica, (May 15), 237-256.

Smith, Beverly A. (1982). “Women's Work— Trifles'?" International Journal of Women's Studies, 5(2), 172-84.

Stein, K. F. (1987). “The Women's World of Glaspell's Trifles.” Women in American Theatre, ed. H. K. Chinoy and L.W. Jenkins. New York: Theatre Communications Group.

Wortham, Simon Morgan. (2010). The Derrida Dictionary. London: Continuum. 